\title{
A NEW CLASSIFICATION OF THE CESTODE ORDER PROTEOCEPHALIDEA MOLA
}

\author{
Amilcar Arandas Rego ${ }^{1}$
}

\begin{abstract}
The morphology, ontogeny, life-cycles and distribution of species of the Order Proteocephalided (Cestoda), is discussed. A brief historic of the classifications is presented. The actual scheme of taxonomy of WOODLAND (1924-1935) is criticicized and a new classification for the group is proposed. The phylogenetic uniformity of Proteocephalideans is reestablished with this classification. The genera of Monticellidae (sensu WoODLAND) are transferred to the subfamilies Protencephalinae and Corallobothrimae. Only one family is accepted in the Proteocephalidea. Proteocephalidae La Rue. 1911; with five subfamilies: Protencephalinae. Corallobothrinae. Sandonellimae. Gangesinae and Acanthotaenimae.

KEY WORDS, Cestoda. Proteocephalidea. new classification. taxonomy
\end{abstract}

The members of the Order Proteocephalidea are mostly found in freshwater fishes, but they also appear in amphibians and reptiles. Most genera and species of proteocephalids inhabite hosts from tropical regions. A fewer number of genera are found in temperate areas, however, species infesting freshwater fishes are found in rivers in circumpolar areas.

The proteocephalids present a scolex with single suckers, reminescent of the ones found in the terrestrial Cyclophyllidea. The reproductive system, especially the vitellaria, is similar to the marine Tetraphyllidea. The Proteocephalidea originated from primitive tetraphyllidean stock in brackish or fresh water. Note that the actual proteocephalids are specialized in freshwater hosts and the tetraphyllideans are found in marine elasmobranchs. It is believed that the evolved Cyclophyllidea originated from a line of proteocephalids specialized in terrestrial reptiles, such as the actual Varaniids. It is interesting to refer to the monotypic Tejidotaenia Freze, 1965, a parasite of Surinam (South America) monitors, that has succeeded in transferring from a freshwater host to a terrestrial host.

The Proteocephalidea is a very old group of helminths and knowledge of it

could be the key to understanding the phylogeny of the Cyclophyllidea and their terrestrial vertebrate hosts, and their evolution, since their appearence of proteocephalids in bony fishes in the Ordovician-Silurian.

\section{HISTORICAL}

The species of proteocephalideans were included in the genus Taenia by Goeze, Gmelin, Zeder and Frölich, distinct helminthologists of the XIX century.

1) Departmento de Helmintologia. Instituto Oswaldo Cruz. Caixa Postal 926. 20(0)1-90() Rio de Janeiro. Brazil. Research fellow of $\mathrm{CNPy}$ 
RUDOLPHI (1808-1810) organized systematically the helminths until that time. After Rudolphi appeared the important works of DuJARDIN (1845) and DIESING (1850) - citations by WARDLE \& MC LEOD (1952). Diesing (1850) in his Systema Helminthum, included several helminths from South America, including species collected by Natterer in fishes from Mato Grosso (Central Brazil) and Amazon.

Until the publication of the important paper of MonTICELLI (1892) the Cestodes from freshwater fishes were not yet characterized as a group independent from Taenia. Monticelli made a careful study of the group, listing twenty species of proteocephalids under the name Tetracotylus. LONNBERG (1894) proposed the name Ichthyotaenia for this group of fish cestodes. Previously, WEINLAND (1858) (cited by WARDLE \& MC LEOD (1952), proposed the name Proteocephalus to designate some species that nowadays we know as proteocephalids. Notwithstanding, the validity of the name Proteocephalus, it was questioned by many authors, until LA RUE (1914) established the validity of the genus, the most important of the Order Proteocephalidea. In his revision, LA RUE (1914) redescribed the known species and defined Monticellia in the following words: "Small head, globose, without folds or lappets tissue encircling suckers. Suckers sessile and without accessory areola. Testes, vitellaria and uterus entirely outside of the inner longitudinal muscle-sheat. Vitellaria composed of scattered follicles which form, broad lateral field. Numerous testes, in a single broad field between vitellaria. Uterus ventral, with many lateral pouches. Marginal genital pores, irregularly alternating. Bilobed ovary, situated partly within and partly outside the inner muscle-sheat. Type genus: M. coryphicephala (Monticelli, 1891)". LA RuE added: "the writer suggests for it the family Monticelliidae".

HARWOOD (1933) discussed the classification of Proteocephalids and criticized the value of the inner longitudinal muscles in the taxonomy of the group; he commented that "we find ample evidence that characters involving the muscular system may be and, indeed, frequently are variable. In a number of these worms there is no inner muscular sheath, at least in the greater part of strobila, and the distinction between medulla and cortex is entirely lost"; and: "the inner longitudinal muscular layer may be extremely variable, even in a single species, and great caution must be exercised in assigning generic value to any variation of it ".

WOODLAND (1924-1935) studied a great quantity of material collected in South America (Amazon) and Africa; in sucessive papers he revised the taxonomy of proteocephalids and thus provided the principles of the actual classification. Woodland recognised differences in the internal arrangement of the gonads denoting subfamily distinctions, and differences in scolex structures as denoting generic and specific characteristics. WOODLAND (1933a,c, 1934b) accepted one family with eight subfamilies:

Proteocephalidae La Rue, 1911

Proteocephalinae Mola, 1929

Zygobothriinae Woodland, 1933

Marsipocephalinae Woodland, 1933

Ephedrocephalinae Mola, 1929 
Peltidocotylinae Woodland, 1934

Monticelliinae Mola, 1929

Rudolphielliinae Woodland, 1935

Endorchiinae Woodland, 1934

WOODLAND contradicted the value of the characteristics of scolex, suckers, rostellum with hooks and metascolex in the definition of subfamilies and genera; which resulted in a reduction of well defined genera, such as Acanthotaenia, Gangesia and Corallobothrium, that were included in Proteocephalus. It is curious that WOODLAND (1925) previously stated: "It is evident therefore that the cortical or medullary situation of the vitellaria is a character of no more than generic value", and more: ".. that compels us to conclude that they all belong to the family Proteocephalidae and that therefore there is no justification for segregating them into a separate family, LA RUE "Monticelliidae, merely because the extension of the testes and other organs into the cortex".

WARDLE \& MC LEOD (1952) and YAMAGUTI (1959) agreed almost completely with Wodland's classification scheme. WARDLE \& MC LEOD (1952) classified the proteocephalideans in a rank of the order but restored the name Proteocephalidea Mola, 1928, according to the law of priority.

FREZE (1965) reviewed the proteocephalideans and subdivided the group more extensively than had previously been done. He utilized the internal arrangement of the gonads and relative development of uterus as superfamilial to subfamilial characters. He noted: "I emphasize the evolutionary isolation of the monticelliid branch of Proteocephalata, characterized by the extrapolation of the gonads into the cortical parenchyma". He gave minor taxonomic importance to the vitellaria and concluded: "In typical proteocephalids only auxiliary glands (vitellaria) can pass into the cortex". FREzE also proposed a new family Ophiotaeniidae, based on some assumptions of morphology and life-cycle of Ophiotaenia species.

\section{Classification of Freze (1965)}

Suborder Proteocephalata Spassky, 1957

Proteocephaloidea Southwell, 1930

Proteocephalidae La Rue, 1911

Proteocephalinae Mola, 1929

Paraproteocephalinae Freze, 1963

Corallobothriinae Freze, 1965

Gangesiinae Mola, 1929

Sandonelliinae Khalil, 1960

Zygobothriinae Woodland, 1933

Ophiotaeniidae Freze, 1965

Ophiotaeniinae Freze, 1965

Acanthotaeniinae Freze, 1963

Monticellioidea Freze, 1963

Monticelliidae La Rue, 1911 


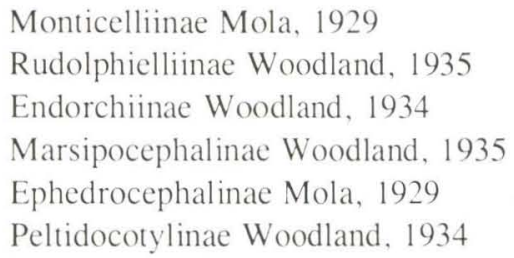

BROOKS (1978) criticized the scheme of FREZE (1965), reducing the taxonomic value of the uterus, attributed by FREZE in the determination of the Monticeliid's subfamilies. BROOKS considered the uterus as of unique origin. He accepted two families, Proteocephalidae, characterized by its vitellaria situated in the medulla, and Monticelliidae, whose species have the vitellaria located in the cortex. Differing from FrEZE (1965), Marsipocephalinae is placed in the Proteocephalidae group, and Zygobothriinae in Monticelliidae group. Brooks did not accept the Ophiotaeniidae; being separated from Proteocephalidae. He accepted only one genus, Proteocephalus, to the species classified as Ophiotaenia and Proteocephalus.

SCHMIDT (1986) in his treatise of tapeworms, agreed in general terms with the classification of Proteocephalidea, but reduced the number of genera, especially the genera of Monticelliidae.

REGO (1987, 1994) accepted the current classification of Proteocephalidea, but criticizes the system of WOODLAND, noting that the finding of intermediate forms between proteocephalids and monticelliids, would necessitate a reavaluation of the taxonomy of the group.

In recent years a quantity of papers have appeared that describe new forms of proteocephalids and monticelliids from South America. Some of these species were provisionally classified, due to the difficulties of the authors to decide if the gonads and vitellaria of these forms are medullary or cortical. Some of these papers are: BROOKS (1978), BROOKS \& DEARDORFF (1980), BROOKS \& RASMUSSEN (1984), Brooks et al. (1991), Chambrier (1987, 1988, 1989, 1990), Chambrier et al.' (1991), Chambrier \& Rego (1994a, 1995), Pavanelli \& Rego (1989, 1991, 1992), REgO (1984, 1985, 1987, 1989-1992, 1994), REGO \& PAVANELli (1985, 1987, 1990, 1992), SCHAEFFER \& REGO (1992).

\section{REMARKS}

In order to have a better understanding of the problem of the taxonomy of the group, It will be commented on some aspects of its morphology, ontogeny, life-cycles and distribution of proteocephalids.

\section{Morphology}

The resemblance of the scolex and suckers of proteocephalids and cyclophyllideans is more apparent than real. The scolices of Cyclophyllidea are not really mobile; by contrast, the suckers of Proteocephalidea are very mobile, being capable of being pushed out, forward or backward or laterally, and retracted; this is characteristic of the primitive Orders of Cestoda. The musculature of proteo- 
cephalids scolex is not sufficiently differentiated to give it a constant form and as the name implies, it is constantly changing. In respect to the movement of the scolex and the action of the suckers, the proteocephalids resemble more the tetraphyllideans, but differing from them, the suckers are sessile; deep grooves between the suckers sometimes give the scolex a lobed appearance causing the suckers to be proeminent. In several species of Proteocephalus, we can find an apical rudimentar sucker (fifth sucker) (Fig. 1) or an apical organ that consists of glandular-muscle elements (Fig. 2), a structure that is found in Nomimoscolex and other genera.

The forms of the suckers are varied; there are unguiculate protrusions in the suckers of Harriscolex kaparari, auriculate projections in Houssayela sudobim, apical lappets, in Sandonella sandoni, suckers with a sphincter as in Marsypocephalus and Megathylacus and spines on suckers borders, in Spasskyelina (Figs 6, 4, 7, 3, 5).

The "normal" condition of suckers in proteocephalids is uniloculate, but we found variations of the type, such as notched suckers in Crepidobothrium; bilobate suckers in Amphoteromorphus; biloculate suckers in Peltidocotyle, Tejidotaenia and Goezeella: triloculate suckers in Gibsoniela: tetraloculate in Deblocktaenia. There are also uniloculate suckers with two apertures in Zygobothrium: and two compartments with one aperture in Brayela (Figs 8, 12, $23,10,13,15,11,14,16)$ The reptilian genera Ophiotaenia, Crepidobothrium, Macrobothriotaenia, Tejidotaenia and Deblocktaenia, exhibit a gradation, from the simple uniloculate suckers as in Ophiotaenia, notched uniloculate suckers, in Crepidobothrium, to tetraloculatate suckers, as in Deblocktaenia (Figs 8-11).

The metascolex is defined as a proliferation of neck tissue, encircling the suckers; occurring in several genera of proteocephalids, limited to the parasites of siluroid fishes. It is a character easily recognised and distinctive (HARWOOD 1933). It is "collar-like" as in Corallobothrium and Goezeella, or the metascolex is reduced, limited to the base of suckers, in Choanoscolex abscisus (Riggenbach, 1896). There exists also a third type of metascolex, originating from the proliferation of tissue around each sucker, as described by BROOKS \& RASMUSSEN (1984) to Amphoteromorphus praeputialis Rego, Santos \& Silva, 1974 (Figs 17, 18, 25). Some species, especially from South America have furrows and wrinkles in the scolex and neck, making it difficult to decide about the existence of a true metascolex; such is the case for instance in the species Nomimoscolex pirarara (Woodland, 1935), whose scolex is sometimes inflated, with furrows on it (Fig. 26). Species with metascolex have uniloculate and biloculate suckers; in one species, Othinoscolex lenha Woodland, 1933, suckers were not observed (Fig.24).

The Acanthotaeniinae have scolex and the anterior part of the strobila is covered by spines, and the apical region of scolex developed a "piercing organ" (Fig. 27).

Gangesiinae exhibit a kind of rostellum with one or more rows of hooks, comparable to the rostellum with hooks in Taeniidae (Cyclophyllidea); this is a interesting case of homoplasie, a convergent evolution (Fig. 28). 

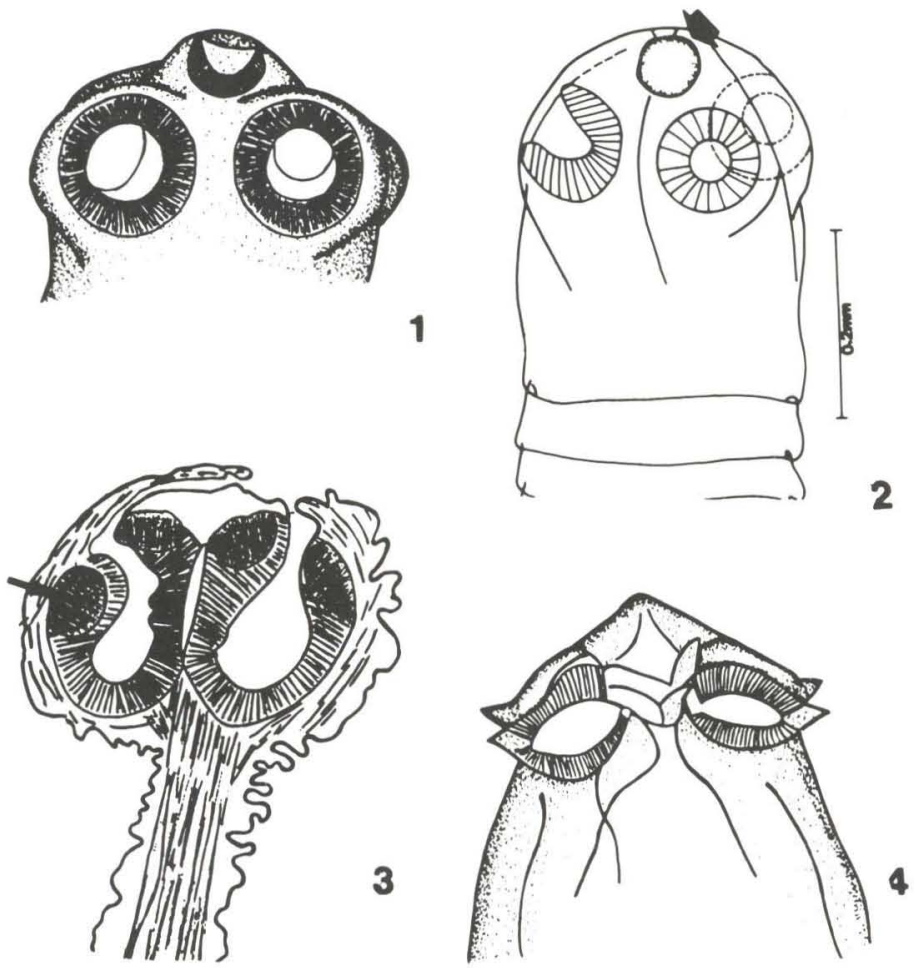

Figs 1-4. (1) Proteocephalus osculatus (Goeze, 1782), scolex, after Rego (1994); (2) Nomimoscolex piraeeba Woodland, 1934, scolex with apical gland (arrow), after REGo (1991); (3) Megathylacus jandia Woodland, 1934, section of scolex with sphincter (arrow), after REGo (1994); (4) Houssayela sudobim (Woodland, 1935), after REGo (1994).

In the proteocephalids which are considered primitive, mature and gravid proglottids are wider than they are long, however, most of the known species have proglottids longer than they are wide or at times even square. Generally the strobila is acraspedote, but some species have a kind of vellum, being craspedotes, as in Zygobothrium megacephalum Diesing, 1850 and Myzophorus pirarara Woodland, 1935 .

In most species of proteocephalids, the distinction between cortex and medulla is easily seen, provided by a developed system of longitudinal muscle fibres, but in some species the distinction is not possible, due to the practically inexistent musculature being inconspicuous. In some species, especially from South American proteocephalids, the medulla is reduced to a thin strip and by contrast the cortex is greatly enlarged, to accomodate the gonads and uterus; however this is not a rule; there is species of Monticellia with developed muscles and others whose musculature is inconspicuous. In Proteocephalus from South America fishes, some species exhibit the same features (Figs 29, 31a,b, 30). 


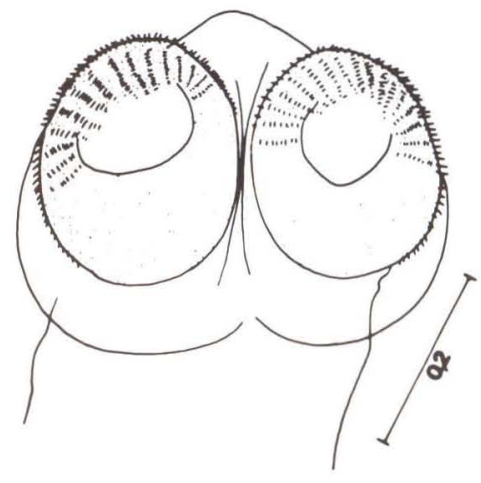

5
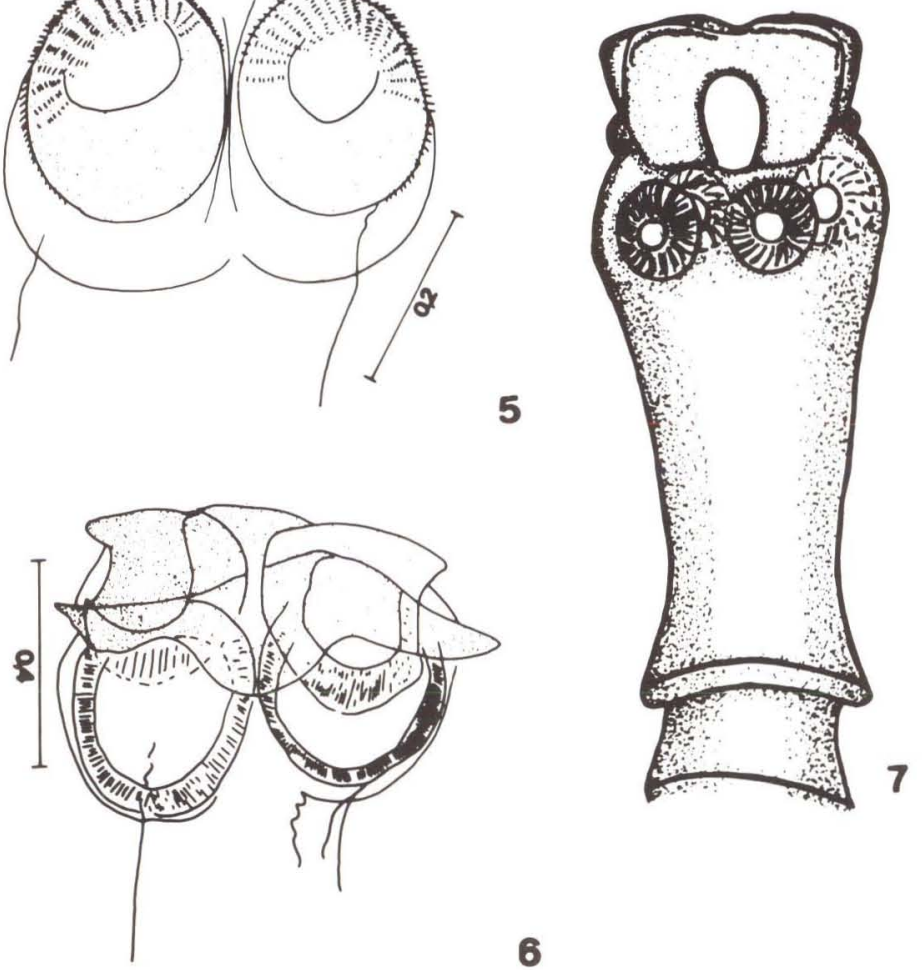

Figs 5-7. Scolex. (5) Spasskyelina spinulifera (Woodland, 1934); (6) Harriscolex kaparari (Woodland, 1935); (7) Sandonella sandoni (Lynsdale, 1960). All after REgo (1994).

In proteocephalids the vitellaria is medullar or cortical; but it is not an absolute rule; in some genera, as Nomimoscolex, Proteocephalus and Gibsoniela, some vitelline follicles are located between the longitudinal muscles, some are in the cortex and others in the medulla (Fig. 32). That situation was designated paramuscular by CHAMBRIER (1990). It is difficult to ascertain the polarity, in the evolution, of the vitellaria.

In characteristic proteocephalids, the vitellaria is represented by two wide lateral bands, passing along the lateral limits of the parenchyma, from the anterior to the posterior part of proglottid margin. There are variations; in the genera Amphoteromorphus and Goezeella, the vitellarian follicles being arranged in a triangular shape; in Paraproteocephalus the vitelline follicles curve in towards the ovary, assuming an L-shaped form. In Sandonella the vitellaria is concentrated in two massive bodies posterior to the ovary (Figs 36, 35, 33, 37, 38). The last form could represent a tendency toward concentration of vitellaria, as observed in the order Cyclophyllidea. 

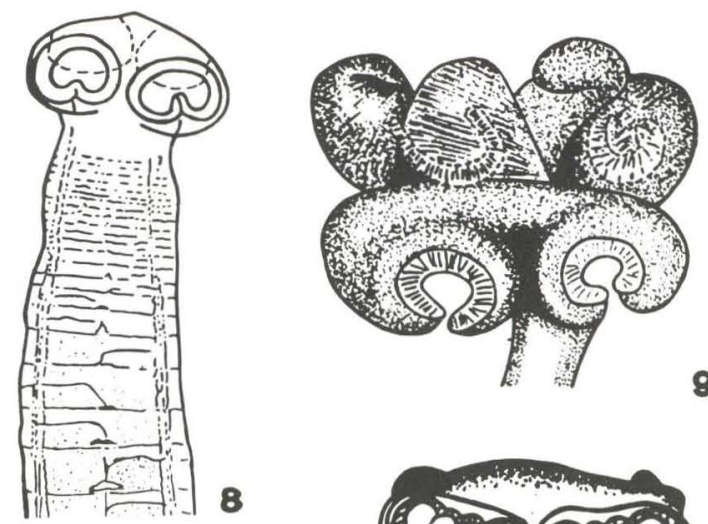

9

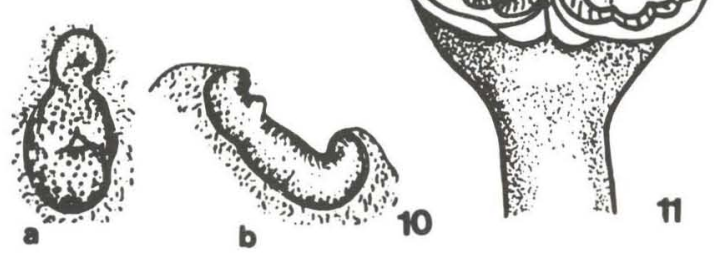

Figs 8-11. (8) Crepidobothrium gerrardi (Baird, 1860), scolex, after Rego (1994); (9) Macrobothriotaenia ficta (Meggitt, 1927), scolex, after REGO (1994); (10) Tejidotaenia appendiculata (Baylis, 1947), (a, b) frontal and lateral view of sucker, after Freze (1965); (11) Deblocktaenia ventosaloculata (Deblock, Rosé \& Broussart, 1962), scolex, after REGo (1994).

The ovary is of the tetraphyllidean type, biwinged or bilobate, and it is unilaminar. The ovary originated in the medulla, even in the genera whose ovary invades the cortex, the lobes crossing between the longitudinal muscles fibres.

The testes are primarily medullary, but in monticelliids from South America and Marsipocephalus from Africa, they are situated in the cortex. Generally the testes occupy one or two layers of parenchyma.

Concerning the uterus, it is generally medullar, but in some genera, as Monticellia and Othinoscolex, it is situated mostly in the cortex. In Sandonella there is an uterine reservoir situated in the cortex. However, the origin of the uterus is always medullar, but its developing parts can invade the cortex. It is clear that the position of the uterus in parenchyma is not a reliable character to separate taxa, as utilized by previous authors. The uterus begins as a longitudinal tube; sometimes preformed in some species; from this tube emerges lateral outgrowths, diverticula, that is the primary condition of proteocephalids. There are some variations, for instance in Paraproteocephalus, the diverticula develops anteriorly and posteriorly, instead of laterally (Figs 34,37 ). We can find other modifications in Sandonella, the uterus being transformed into a voluminous sac. Egg capsules are rare in Proteocephalids, but they are found in Kapsulotaenia (Acanthotaeniinae). The eggs are round or sometimes spindle-shaped, with two embryonic 


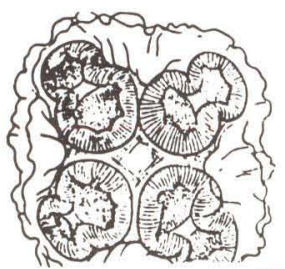

12

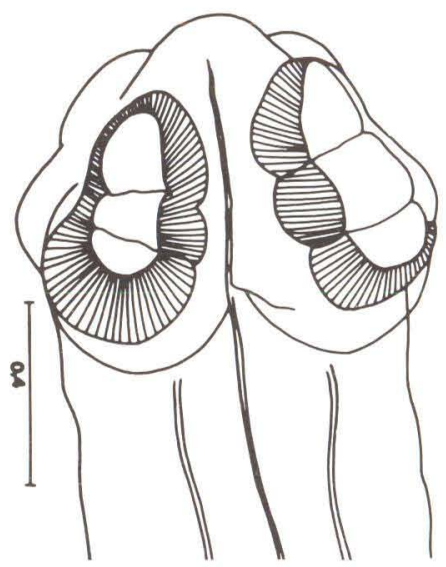

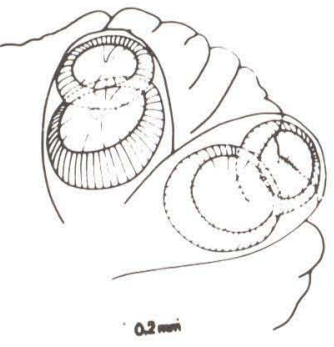

13

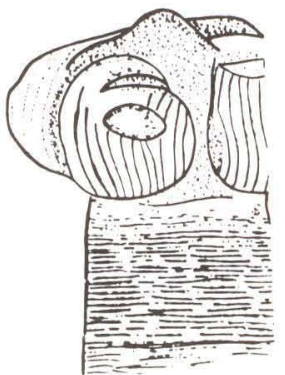

14

15

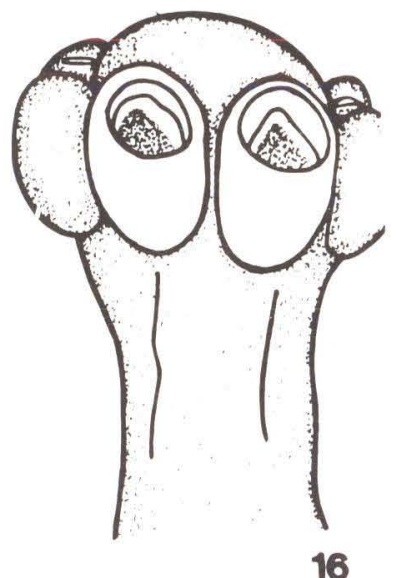

Figs 12-16. (12) Amphoteromorphus peniculus Diesing, 1850, scolex section; (13) Goezeela siluri Fuhrmann, 1916, scolex part. Original; (14) Zygobothrium megacephalum Diesing, 1850, scolex; (15) Gibsoniela mandube (Woodland, 1935), scolex; (16) Brayela karuatayi (Woodland, 1934), scolex. All after REGo (1994).

envelops, one inner and one outer membrane. The external membrane is very delicate and variable in form; polar filaments can exist in some species. The hooks of the onchosphera sometimes are not seen in proteocephalids from South America freshwater fishes.

\section{Ontogeny}

FreZE (1965) and FrEEMAN (1973) discussed the existence of a general ancestral tetraphyllid stem. They considered that, the separation of these two cestodes branches from the common ancestral stem took place in the very distant past, leading to Acanthodi and Elasmobranchi, in the Ordovician to the Silurian. It is generally accepted that proteocephalids originated in the Gondwana. Note that most of the actual species are present in the Continents that derived from the Gondwana (actually South America, Africa, India, Australia). 
Pattern of evolution of proteocephalideans and cyclophyllideans, adapted from FREEMAN (1973):

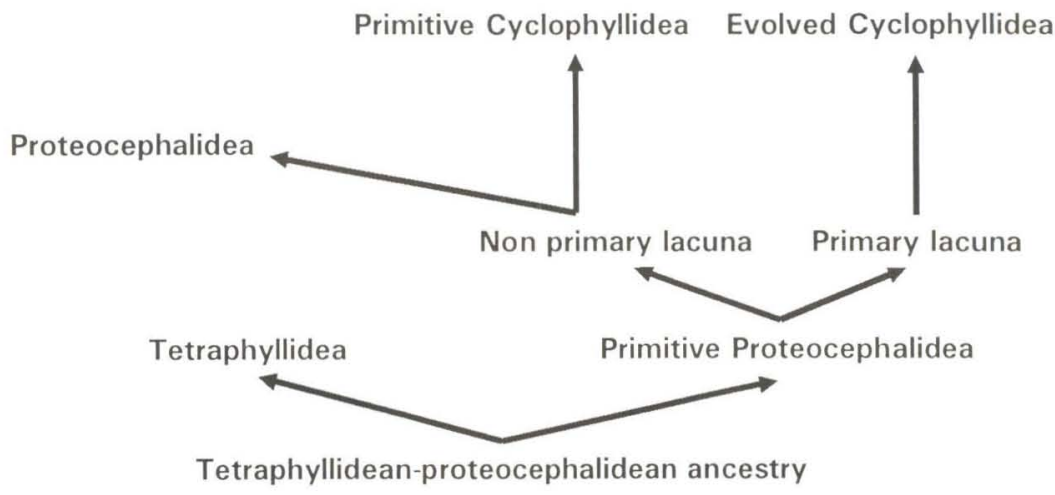

Some authors assumed that a tetrafossate tetraphyllidean-proteocephalidean was the ancestor from which modern tetraphyllideans and other marine forms, proteocephalideans (freshwater) and cyclophyllideans (terrestrial) evolved. Other authors suggested that most primitive cestodes were neither di nor tetrafossate, having rather a single apical sucker-like or a glandular holdfast; that structure may be atrophied, in the form of a glandular apical mass present in many actual species (apical glandular organ of Proteocephalus, Nomimoscolex and other genera).

There is little doubt that Cyclophyllidea evolved from Proteocephalidea (WARDLE \& MC LEOD 1952; JARECKA 1975). Proteocephalidea and Tetraphyllidea are sister groups, which is demonstrated by morphological similarities.

FREZE (1965) considered the proteocephalideans a monophyletic group.

Many authors believe that the genus Proteocephalus exhibits archetypic characters, such as uniloculate suckers, abscence of metascolex and vitellaria, medullar and lateral. However, HENNING, cited in BROOKS (1985) objected to the use of hypothetical idealized archetype ancestors. He asserted that all species are composite of ancestral and derived traits, therefore, there are no such things as archetypes that by definition are all primitive.

There is agreement that the presence of metascolex is an acquisition that facilitates the attachment to the wall of intestine; but the authors speculated if the appearence of metascolex in genera from other continents could be a evolutionary convergence or whether the isolation of these forms followed the ancestral stem, a synapomorphic characteristic.

Concerning the vitellaria, Proteocephalideans, except Monticelliids from South America, most Lecanicephalideans, most Tetraphyllideans, the Cyclophyllideans and a few Pseudophyllideans have medullary vitellaria. The vitellaria cortical is found in Monticelliids, most Pseudophyllideans, some Tetraphyllideans and Lecanicephalideans and all Trypanorhyncha; it is difficult to decide which condition is ancestral, plesiomorphic, but it is probably that in Proteocephalids the primitive condition is the location in the medulla, with follicles disposed laterally 

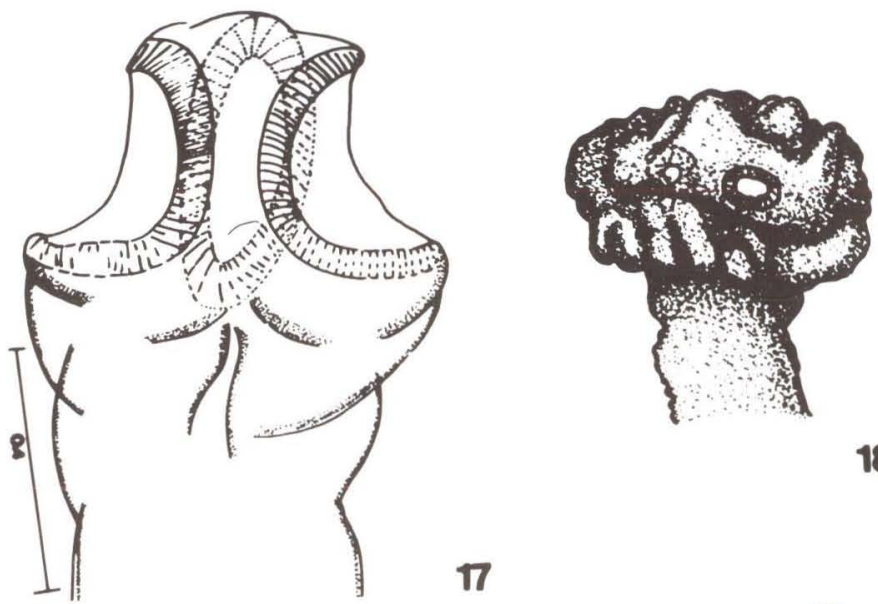

18
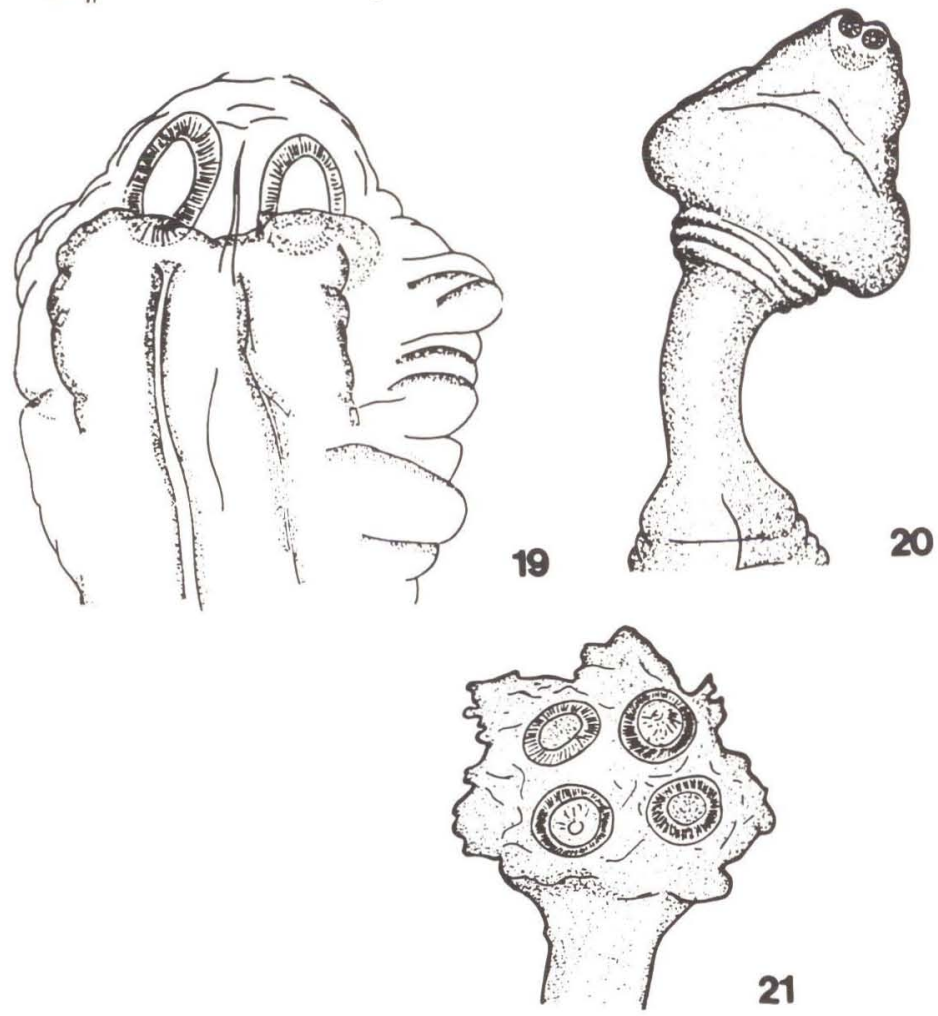

Figs 17-21. Scolex. (17) Choanoscolex abscisus (Riggenbach, 1895); (18) Corallobothrium fimbriatum (Essex, 1928); (19) Spatulifer rugosa (Woodland, 1935); (20) Jauella glandicephalus Rego \& Pavanelli, 1985; (21) Corallotaenia parva (Larsch, 1941). All after REGo (1994). 

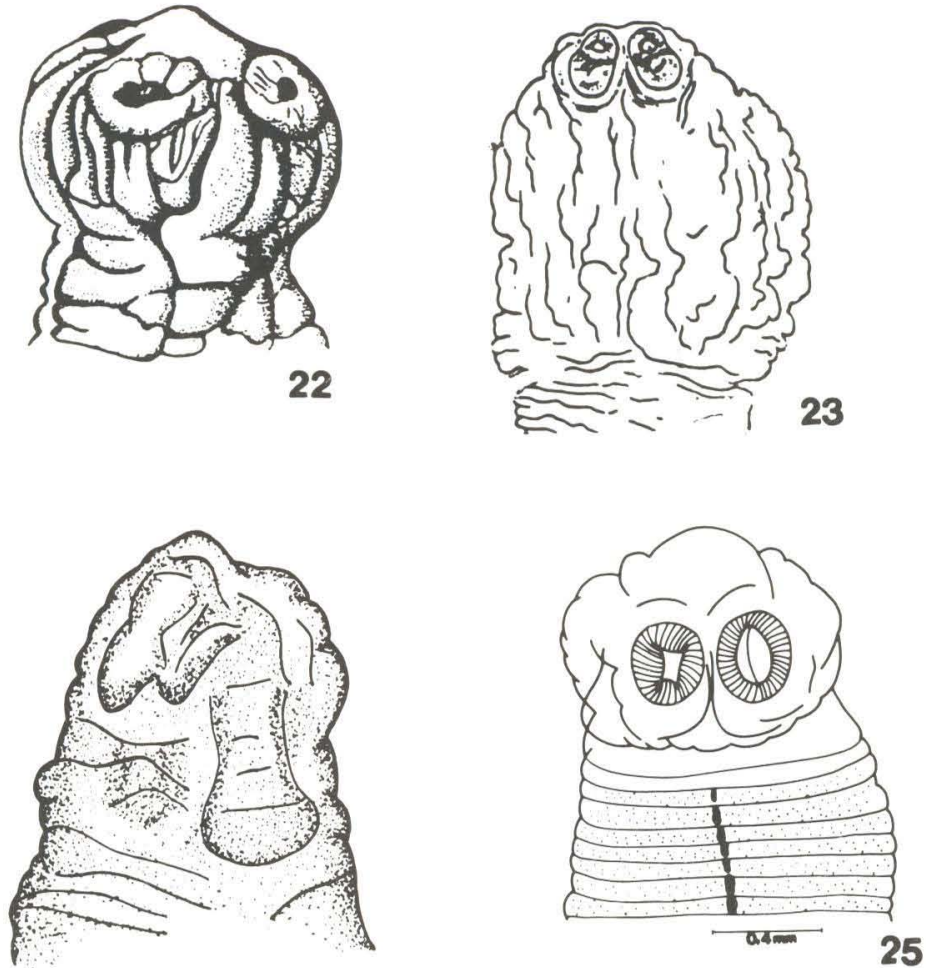

24

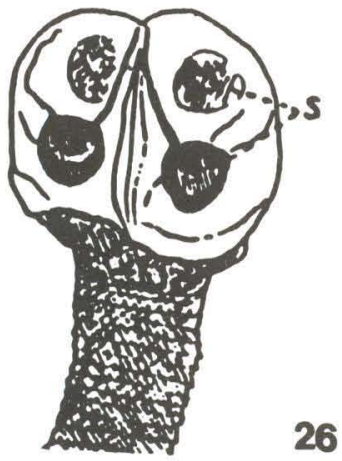

Figs 22-26. (22) Megathylacoides giganteum (Essex, 1928), scolex, after REGo (1994); (23) Peltidocotyle rugosa Diesing, 1850, scolex, after Fumrmann (1934); (24) Othinoscolex lenha Woodland, 1933, scolex, after REGo (1994); (25) Amphoteromorphus praeputialis Rego, Santos \& Silva, 1974, original; (26) Nomimoscolex pirarara (Woodland, 1935), scolex inflated, (s) suckers, after WOODLAND (1935). 
and longitudinally. The tendence of the vitellaria to concentrate in a triangular arrangement as in Amphoteromorphus, or concentrate in two massive bodies as in Sandonella, probably is apomorphic, descendent condition, tending to a compact vitellaria, as in Cyclophyllidea.
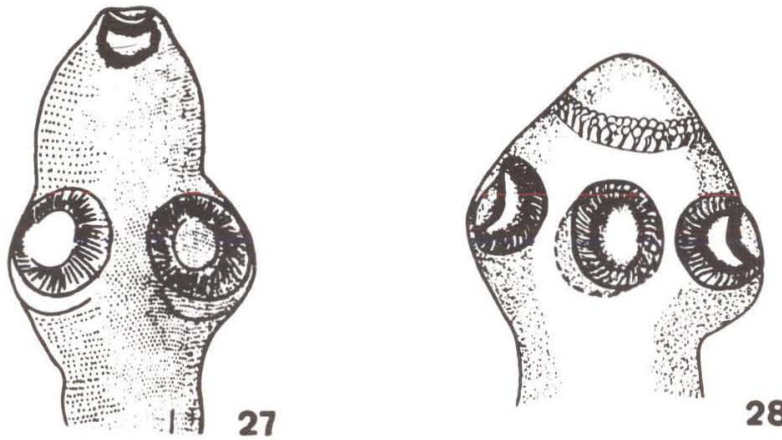

Figs 27-28. Scolex. (27) Kapsulotaenia sandgroundi (Carter, 1943); (28) Gangesia parasiluri Yamaguti, 1934. All after REGo (1994).

\section{Life-cycles}

JARECKA (1975) stated that Proteocephalids and Cyclophyllids are viviparous organisms, meaning that onchosphera matures in the uterus, not in the external medium, as occur, for instance, in Pseudophyllideans.

Proteocephalids are cercomeric forms, discarding the cercomer in intermediate hosts. The authors believe that some proteocephalids have a cysticercoid larva between the stages of procercoid and plerocercoid. The form cysticercoid was found in Corallobothriinae and in Ophiotaenia (FREEMAN 1973; JERECKA 1975). These cysticercoids are homologous with the cysticercoid stage of Cyclophyllidea; it possibly represents a symtom of the complication of the life-cycle in proteocephalids.

If the cysticercoid finds itself in the intestine of a reservoir host, it develops into a plerocercoid, but if the cysticercoid remains encysted in the organs it is a dead end, due to the impossibility for it to reach sexual maturity. The stage of cysticercoid could be an obligatory phase of evolution in the reservoir host while the definitive host is a carnivorous fish. To note that encysted cysticercoids are common in South American freshwater fishes (SCHAEFFER \& REGO 1992), by contrast, the presence of plerocercoids is not so common in these fishes. Unfortunately, it is not know enough about the life-cycle of the South American proteocephalids to evaluate the role of the cysticercoids in the dispersion of the species. 

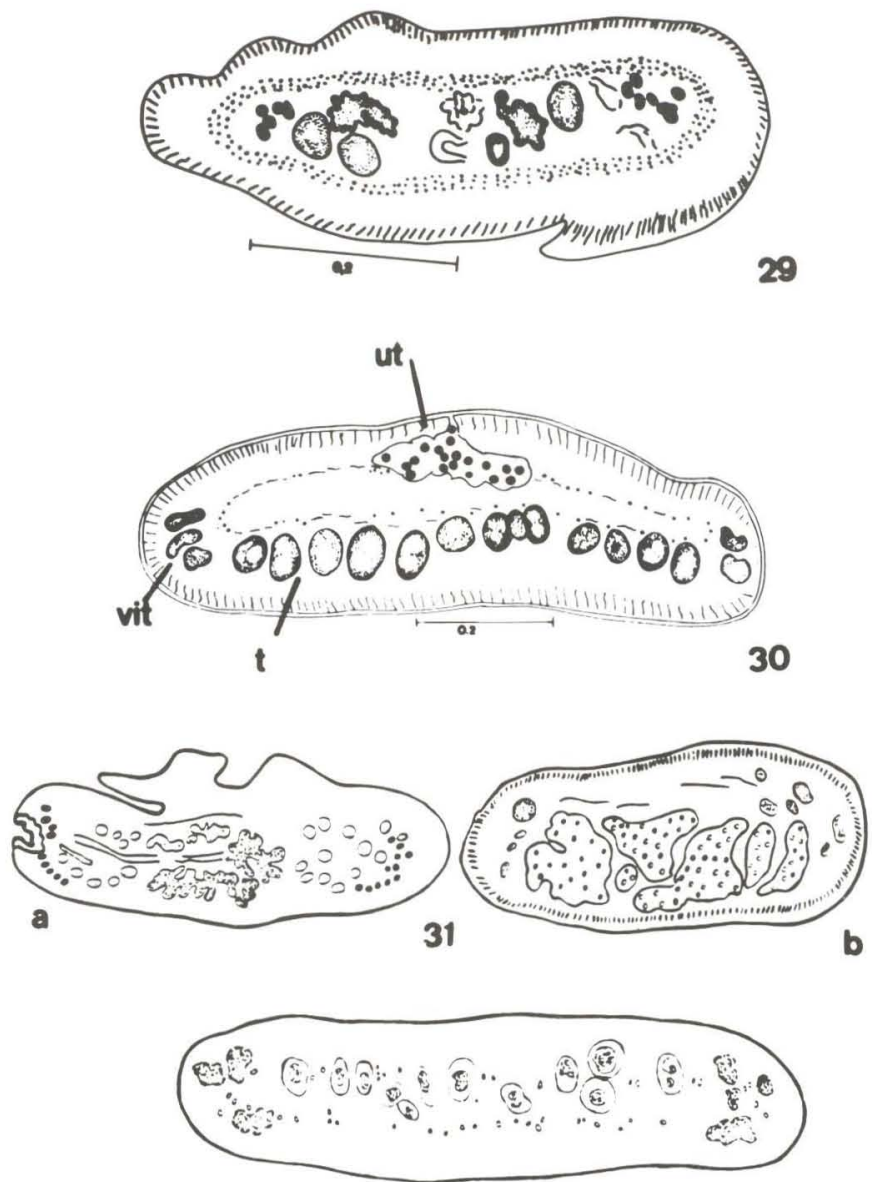

32

Figs (29-32). Proteocephalus sp. section, gonads and vitellaria medullary, longitudinal musculature well developed, original; (30) Choanoscolex abscisus (Riggenbach, 1896), section of proglottid, gonads and vitellaria cortical, (ut) uterus, (vit) vitellaria, (t) testes, after REGO (1990); (31) Sciadocephalus megalodiscus Diesing, 1850, sections of proglottids, no distinction between cortex and medulla, after REGO (1994); (32) Nupelia portoriquensis Pavanelli \& Rego, 1991, section of proglottid, gonadas and vitellaria partly medullar, partly cortical, after REGo (1994).

\section{Distribution}

The cosmopolitan genera Proteocephalus and Ophiotaenia have a great geographical dispersal, however, many of the proteocephalids genera are regional, as the monticelliid genera, limited to South America, and Marsipocephalus, limited to Africa. The greatest concentration of species, specially from Proteocephalus, occur in the Northern hemisphere, where the fewest genera of the order occur; most of proteocephalid genera are found in the Southern hemisphere. The 

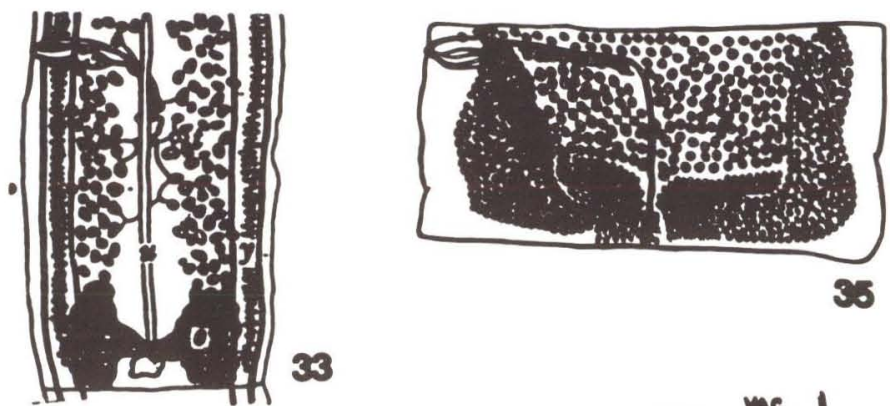

33
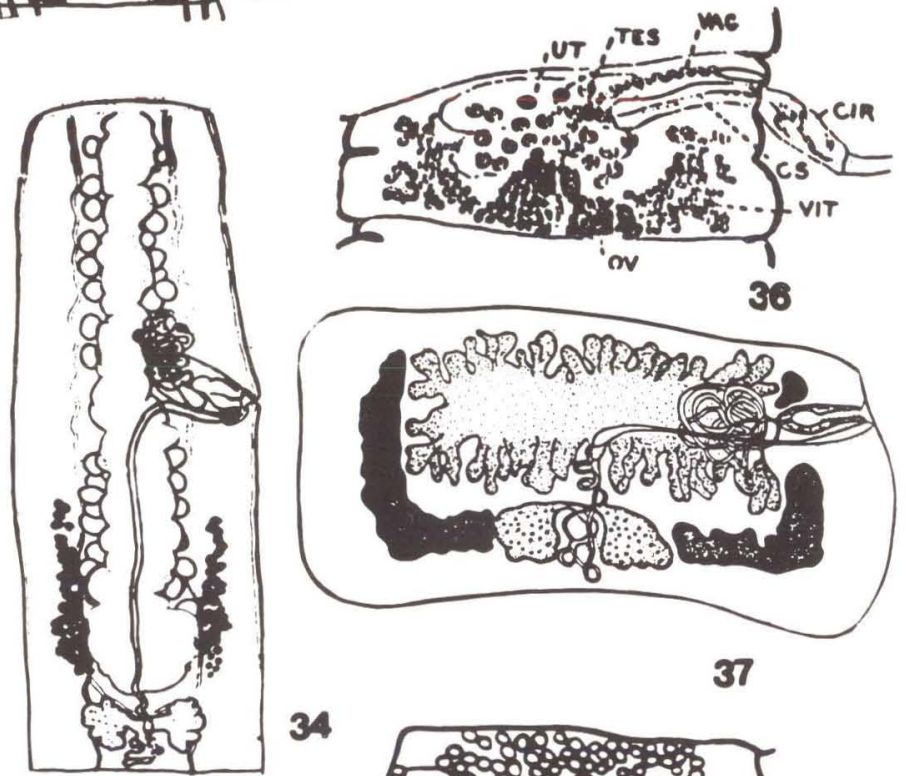

34

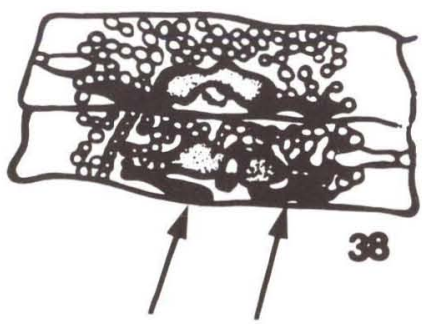

Figs (33-38). Ophiotaenia filaroides La Rue, 1909, mature proglottid, vitellaria lateral, after WARDLE \& MC LEOD (1952); (34) Vaucheriella bicheti de Chambrier, 1987, vitellaria lateral, limited to posterior part of proglottid, after REGO (1994); (35) Goezeella siluri Fuhrmann, 1916, vitellaria developed, curves toward the ovary, after BROOKS \& RASMUSSEN (1984); (36) Amphoteromorphus peniculus Diesing, 1850, vitellaria triangular, (ut) uterus, (test) testes, (vag) vagina, (cir) cirrus pouch, (vit) vitellaria, (ov) ovary, after WoodLAND (1933); (37) Paraproteocephalus parasiluri (Zmeev, 1936), vitellaria L-shaped, after REGo (1994); (38) Sandonella sandoni (Lynsdale, 1960), vitellaria in the form of two massive bodies posterior to ovary (arrow), after REGo (1994). 
Siluriform fishes are the principal hosts of proteocephalids in South America, while in Northern hemisphere a great diversification of hosts, beyond Siluriforms, has occurred (BROOKS 1978).

The proteocephalidean fauna of the Ethiopian region is somewhat similar to that of South America in a number of nearly related genera of parasites of Siluroid fishes, especially Marsipocephalus and Proteocephalus.

There is a wide distribution of the highly organized Gangesiinae. The genus Silurotaenia, and especially Gangesia, emphasize the connections with the Paleartic regions; Electrotaenia with the Ethiopian region, and genus Vermaia, a parasite of the Indian Siluroids.

The curious genus Macrobothriotaenia (Proteocephalinae) parasites of snakes from Madagascar, whose fauna is poorly studied. This genus is related to the South American Crepidobothrium. The Corallobothriinae consists of numerous genera, whose metascolex is well developed or not; . It is added to this subfamily, beyond Corallobothrium, Corallotaenia and Paraproteocephalus (from Russia), the following genera from South America:

Goezeella, Spatulifer, Megathylacus, Rudolphiella, Amphoteromorphus, Jauella, Ephedrocephalus, Peltidocotyle, Othinoscolex, Woodlandiella and Choanoscolex.

The Acanthotaeniinae parasitize reptiles, with a great dispersal of its genera Acanthotaenia and Kapsulotaenia; in Varanids and Monitors from Africa, India, Malaysia, Indonesia and Australia; BROOKS \& SCHMIDT (1978) described a species of Acanthotaenia from Puerto Rico. The Gangesiinae and Acanthotaeniinae are related subfamilies.

\section{DISCUSSION}

The scheme of WOODLAND was useful for decades, but with the discovery of new forms, with characters intermediate between the proteocephalids and monticelliids (sensu WOODLAND), it reduced the value of the arrangement of vitellaria and gonads in the cortical parenchyma, as characteristically distinctive. Unfortunatly, the majority of proteocephalid species were described from the Paleartic region (Europe and North America), especially the Proteocephalus species. Since WoOdLAND (1933-1935) few papers have appeared describing South American proteocephalids. In the last years this fauna is being scrutinized, and with the knowledge of the proteocephalideans fauna from that region it became evident that the actual taxonomy of the group, especially of the Monticelliids, needs to be revised. The authors had difficulties in identifying the taxon of many described species; for instance, REGO \& PAVANELLI (1987) described Travassiella avitellina, a species characterized by the apparent absence of vitellaria and longitudinal muscles. Naturally it was not possible to determine the high taxon to which the species belongs. A better example could be the species Nupelia portoriquensis Pavanelli \& Rego, 1991, whose reproductive organs and vitelline follicles are situated partly in the medulla and partly in the cortex, making it impossible to determine the subfamily sensu WoOdLAND. Notice that the well 
known genus Proteocephalus has also species with inconspicuous musculature; the identification of taxa results doubtful.

WOODLAND (1933-1935) and FREZE (1965) suggested that the group of Monticelliids could be characterized by the progressive weakness of musculature of the parenchyma, thus enabling the migration of the reproductive organs to the cortical parenchyma. This is a faulty assertion; there are many examples of Monticelliids with well developed musculature; in species of Goezeella, Amphoteromorphus and Nomimoscolex there are species with developed longitudinal musculature, together with others with inconspicuous musculature. However, in many Proteocephalidae, as in some species of Proteocephalus and Acanthotaenia, the longitudinal musculature is weak or inconspicuous.

The vitellaria is medullar in the majority of species of Cestodes, but the cortical situation of vitellaria is not rare, not only limited to South American species. Vitellaria cortical or partly cortical is present in species of Proteocephalus and Gangesia from other Continents ( $c f$. FrEzE 1965). To complicate, the South American species, Gibsoniela mandube (Woodland, 1935), Houssavela sudobim (Woodland, 1935) and Proteocephalus paraguayensis Chambrier, 1990 have the vitelline follicles situated between the fibres of the longitudinal muscles (paramuscular). It becomes clear that the arrangement of vitelline follicules is not a sufficient character trait to isolate these species from the Proteocephalidae; and of course, the use of only one characteristic to define the taxon family is not reasonable.

The migration of the gonads and uterus to the cortex constitutes an important characteristic, showing an accentuated degree of evolution, but I think it is not necessary to isolate these species from the Proteocephalidae. Note that the Marsipocephalus from Africa have the testes situated in the cortex, as occurs in the monticelliids from South America; it could be a character inherited from a common ancestry in the Gondwana.

Concerning the uterus and ovary, their origin is in the medulla, but developing diverticula of uterus and the lobes of ovary can be introduced into the cortex, passing through the fibres of longitudinal muscles of parenchyma. This character is very common in South American fish proteocephalids.

The author has observed that the cortical situation of these organs is not complete, unlike that represented in the schematic sections of the Woodland 's subfamilies, Monticelliinae, Peltidocotylinae, Ephedrocephalinae and Rudolphielliinae, REGO (1991) invalidated Endorchiinae and genus Endorchis.

In short, the Proteocephalidea is a monophyletic group, with a common ancestry in the Gondwana. There is no justification to isolate a Monticelliidae family, to place the genera that exhibits migration of vitellaria and or gonads to the cortex. However, these characters are considered very important at the level of genera: consequently, it is proposed the elimination of Monticelliidae and its subfamilies. The genera of Monticelliidae are validated and included in the families of Corallobothriinae and Proteocephalinae, depending on the presence or not of metascolex. The subfamilies Sandonelliinae, Gangesiinae and Acanthotaeniinae, are mantained, because they have sufficient characteristics to distinguish them from 
the other taxa. The Marsypocephalinae Woodland, 1933 is eliminated for unnecessary and the genus Marsipocephalus Wedl, 1861 is transferred to Proteocephalinae.

The uniformity of the Proteocephalidea is reestablished with this classification; as mentioned, the available information indicates the monophyletic origin of the group in the Gondwana. The proteocephalideans are a very old group, comparable in this aspect to the Tetraphyllidea; however, they are very evolved, as expressed by the development of certain anatomical features, such as the rostellum with hooks in Acanthotaeniinae, the tendency of concentration of vitellaria in Sandonelliinae, and with the existence of a stage of cysticercoid in the life-cycle of some species. Note that this classification is based solely on morphological concepts, not in phylogenetic analysis. Notwithstanding, it is possible that in the future, discoveries on the life-cycle of South American and African species, and the finding of new forms of Proteocephalids, could carry to some modifications in this scheme.

\section{Proteocephalidea Mola, 1928 \\ Proteocephalidae La Rue, 1911}

Diagnosis. Scolex of varied forms. Reproductive organs medullary or medullary-cortical in varied combinations. Vitellaria medullar, cortical or paramuscular. Parenchyma usually divided into cortical and medullary regions by distinct layer of longitudinal muscle fibres. Parasites of freshwater fishes, amphibians and reptiles. In North America, South America, Africa, Europe, Asia, Australia. Type genus: Proteocephalus Weinland, 1858.

Key to subfamilies:

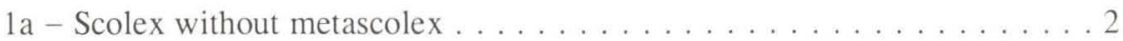

1b - Scolex with metascolex . . . . . . . . . . . Corallobothriinae Freze, 1965

Diagnosis. Suckers covered by folds of metascolex tissue, with or without sphincter; or the metascolex is reduced, with some folds between the suckers or at base of them. Vitellarium and genitalia medullary or cortical-medullary, in varied combinations. In Siluroid fishes from North America, South America, Africa and Russia (Far East). Type genus Corallobothrium Fritsch, 1866.

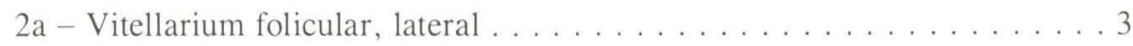

$2 b$ - Vitellarium not follicular, in the form of two massive bodies, posterior to ovary .................. Sandonelliinae Khalil, 1960

Diagnosis. Scolex without metascolex, but with a highly modified apical suctorial organ formed of two lappets. Genitalia medullary. Uterus saccular. Vitellarium near posterior margin of segments. Uterus form round sac that invades cortex. Strobila craspedote. In African osteoglossid fishes. Type and only genus Sandonella Khalil, 1960. 
3a - Scolex lacking rostellum or spines. Vitellarium and reproductive organs medullary or cortical. Scolex globular. Suckers of varied forms . . . . . . . . . . . . . . . . . . . . . . . . Proteocephalinae Mola, 1929

Diagnosis. Rostellum and metascolex absent. Suckers acetabular, uniloculate, biloculate, triloculate or tetraloculate; horny projections may be found. Fifth or apical sucker and an apical glandular-muscular organ may be present. Vitellarium lateral. Gonads and vitellaria entirely medullary or partly medullar-cortical in varied combinations. Cosmopolitan. Type genus Proteocephalus Weinland, 1858.

$3 b-$ Scolex with armed rostellum or "piercing organ". . . . . . . . 4 4a-Scolex with armed rostellum . . . . . . . . . . . Gangesiinae Mola, 1929

Diagnosis. Rostellum armed, non-retractable; one, two or several circles of hooks present. Suckers and neck spined or not. Vitellarium lateral. Ovary bilobed. In Siluroid fishes. Africa, Europe, Asia. Type genus Gangesia Woodland, 1924.

$4 \mathrm{~b}$ - Scolex with specialized rostellum ("piercing organs") of muscular-glandular structure . . . . . . . . . . . . Acanthotaeniinae Freze, 1963

Diagnosis. Scolex and anterior part of strobila covered with dense network of spines. Reproductive organs medullary. Mehlis' gland highly developed. Longitudinal musculature weakly developed. Some species with egg capsules. In reptiles Varanids. Asia, Australia, Puerto Rico. Type genus Acanthotaenia Linstow, 1903.

\section{Proteocephalinae}

\section{Genera:}

Proteocephalus Weinland, 1858 (Syn. Ichthyotaenia Lonnberg, 1894)

Ophiotaenia La Rue, 1911 (Syn. Batrachotaenia Rudin, 1917; Solenotaenia Beddard, 1913; Testudotaenia Freze, 1965).

Crepidobothrium Monticelli, 1900 (Syn. Ophidiotaenia Beddard, 1913).

Travassiella Rego \& Pavanelli, 1987

Macrobothriotaenia Freze, 1965

Brayela Rego, 1984

Gibsoniela Rego, 1984

Tejidotaenia Freze, 1965

Deblocktaenia Odening, 1963

Spasskyelina Freze, 1965

Monticellia La Rue, 1911

Nomimoscolex Woodland, 1934 (Syn. Endorchis Woodland, 1934; Myzophorus Woodland, 1934).

Vaucheriella Chambrier, 1987 
Zygobothrium Diesing, 1850

Houssayela Rego, 1987

Harriscolex Rego, 1987

Nupelia Pavanelli \& Rego, 1991

Cangatiella Pavanelli \& Machado dos Santos, 1991

Marsypocephalus Wedl, 1861 (Syn. Loennbergia Fuhrmann \& Baer, 1925)

\section{Corallobothriinae}

\section{Genera:}

Corallobothrium Fritsch, 1886

Megathylacus Woodland, 1934

Megathylacoides Jones, Kerly \& Sneed, 1956

Corallotaenia Freze, 1965

Paraproteocephalus Chen, 1962

Spatulifer Woodland, 1934

Goezeella Fuhrmann, 1916

Paramonticellia Pavanelli \& Rego, 1991

Choanoscolex La Rue, 1911

Amphoteromorphus Diesing, 1850

Peltidocotyle Diesing, 1850

Othinoscolex Woodland, 1933

Jauella Rego \& Pavanelli, 1985

Woodlandiella Freze, 1965

Ephedrocephalus Diesing, 1850

Rudolphiella Fuhrmann, 1916 (Syn. Amphilaphorchis Woodland, 1934)

Sciadocephalus Diesing, 1850 genera inquirenda

Manaosia Woodland, 1935 genera inquirenda

\section{Acanthotaeniinae Freze, 1963}

\section{Genera:}

Acanthotaenia von Linstow, 1903

Kapsulotaenia Freze, 1963 (Syn. Capsulotaenia Freze, 1965; ? Postgangesia Akhmerov, 1969

\section{Gangesiinae Mola, 1929}

\section{Genera:}

Gangesia Woodland, 1924

Electrotaenia Nybelin, 1942 
Silurotaenia Nybelin, 1942

Vermaia Nybelin, 1942

\section{Sandonelliinae Khalil, 1960}

Type and only genus Sandonella Khalil, 1960

\section{REFERENCES}

BROOKS, D.R. 1978. Evolutionary history of the cestode Order Proteocephalidea. Syst. Zool. 27 (3): 312-323.

1985. Phylogenetic and the future of helminth systematics. Jour. Parasit. 71 (6): 719-727.

Brooks, D.R. \& T.T. DeardorfF. 1980. Three Proteocephalid cestodes from Colombian Siluriform fishes, including Nomimoscolex alovarius sp.n. (Monticelliidae: Zygobothriinae). Proc. Helm. Soc.Wash. 47 (1): 15-21.

Brooks, D.R.; E.P. Hoberg \& P.J. Weekes. 1991. Preliminary phylogenetic systematic analysis of the major lineages of the Eucestoda (Platyhelminths: Cercomeria). Proc. Biol. Soc. Wash. 104 (4): 651-668.

Brooks, D.R. \& G. Rasmussen. 1984. Proteocephalideans cestodes from Venezuelan Siluriform fishes, with a revised classification of Monticelliidae. Proc. Biol. Soc. Wash. 97 (4): 748-760.

BRooks, D.R. \& G.D. SCHMIDT. 1978. Acanthotaenia overstreeti sp.n. (Proteocephalidea) from a Porto Rican lizard, the first Acanthotaeniinae in the new world. Proc. Helm. Soc. Wash. 45 (2): 193-195.

Chambrier, A. DE. 1987. Vaucheriella bicheti n.gen. n.sp. (Cestoda: Monticelliidae, Zygobothriinae) parasite de Tropidophis cf. taczanovskyi) (Steindachner. 1880) (Serpentes: Tropidophidae) des Andes équatoriennes. Rev. Suisse Zool. 94 (4): 829-840.

1988. Crepidobothrium garzoni n.sp. (Cestoda: Proteocephalidae) parasite de Bothrops alternatus Dum. Bibr. \& Dum. 1854 (Serpentes: Viperidae) au Paraguay. Rev. Suisse Zool. 95 (4): 1163-1170.

1989. Revision du genere Crepidobothrium Monticelli, 1900 (Cestoda: Proteocephalidae) parasite d'Ophidiens néotropicaux. II. C. dollfusi freze, 1965. C. lachesidis (Mac Callum, 1921) et conclusions. Rev. Suisse Zool. 96 (2): $345-380$.

1990. Redescription de Proteocephalus paraguayensis (Rudin, 1917) (Cestoda: Proteocephalidae) parasite de Hydrodynastes gigas (Dum. Bibr. et Dum. 1845) du Paraguay. Syst. Parasit. 16: 85-97.

Chambrier, A. DE; M.L. D'Alession \& M.A. CorreA. 1991. Redescription of Proteocephalus jararara (Fuhrmann, 1927) (Cestoda: Proteocephalidae) parasite de Bothrops alternatus (Viperidae) au Brèsil. Rev. Suisse Zool. 98 (1): $15-32$.

Chambrier, A. DE \& A.A. Rego. 1994a. Proteocephalus sophiae n.sp. (Cestoda: Proteocephalidae) a parasite of the Siluroid fish Paulicea luetkeni (Pisces: 
Pimelodidae) from the Brazilian Amazon. Rev. Suisse Zool. 101 (2): 1-8. 1994 (in press). Mariauxiella pimelodi n.gen. n.sp. (Cestoda: Monticelliidae) a parasite of pimelodid siluroid fishes from South America. Syst. Parasitol. 30: 57-65.

DiESING, K.M. 1850. Sechzehn Gattungen von Binnewürmern und ihre Arten.

Denkschr. Kaiser Akad. Wiss. Wien mat.- Nat Class. 9: 171-185.

FREEMAN, R.S. 1973. Ontogeny of cestodes and its bearing on their phylogeny and systematics, p.481-517. In: B. DAWES (Ed.). Advances in Parasitology. New York, Acad press, vol 11,774p.

Freze, V.I. 1965. Principles of Cestodology. Proteocephalata Cestodes of Fishes, Amphibians and Reptiles. Moscow, Edit by K.I. Skrjabin, vol. 5, $538 \mathrm{p}$.

HARWOOD, P.D. 1933. The helminths parasitic in a water moccassin (snake) with a discussion of the characters of the Proteocephalidae. Parasitol. 25 (1): 130-142.

Jarecka, L. 1975. Ontogeny and evolution of cestodes. Acta Parasit. Polonica 23: $93-111$.

LA RUE, G.R. 1914. A revision of the cestode family Proteocephalidae. Ill. Biol. Monogr. 1: 1-350.

LOENNBERG, E. 1894. Uber eine neue Tetrabothriumspecies und die Verwandtschaft verhaltnisse der Ichthyotaenien. Centralbl. Bakt. Parasitenk. 15: 801-803.

Monticelli, F.S. 1892. Notizie suni alcuni specie di Taenia. Boll. Soc. Nat. Napoli 5: 151-174.

Pavanelli, G.C. \& A.A. Rego. 1989. Novas espécies de Proteocefalídeos (Cestoda) de Hemisorubin platyrhynchus (Pisces: Pimelodidae) do Estado do Paraná. Rev. Brasil. Biol. 49 (2): 381-386.

1991. Cestóides proteocefalídeos de Sorubim lima (Schneider, 1801) (Pisces: Pimelodidae) do rio Paraná e reservatório de Itaipu. Rev. Brasil. Biol. 51 (1): 7-12.

1992. Megathylacus travassosi sp.n. e Nomimoscolex sudobim Woodland, 1935 (Cestoda: Proteocephalidea) parasitos de Pseudoplatystoma corruscans (Agassiz, 1829) (Siluriformes: Pimelodidae) do reservatorio de Itaipu e rio Paraná, Pr, Brasil. Mem. Inst. Oswaldo Cruz 87 (Supl. I): 191-195.

Rego, A.A. 1984. Proteocefalídeos (Cestoda) de Phractocephalus hemiliopterus peixe da Amazonia. Mem. Inst. Oswaldo Cruz 79: 257-261.

1985. Proteocephalidea from Amazonian freshwater fishes. New systematic arrangement for the species described by Woodland as Anthobothrium (Tetraphyllidea). Acta Amazonica 13: 86-94.

1987. Cestóides proteocefalídeos do Brasil. Reorganização taxonomica. Rev. Bras. Biol. 47: 202-212.

1989. Cestóides proteocefalídeos da "cachara", Pseudoplatystoma fasciatus (L.) (Pisces: Pimelodidae) de Mato Grosso. Mem. Inst. Oswaldo 
Cruz 84 (Supl. 4): 455-461.

1990. Cestóides proteocefalídeos parasitas de "pintado", Pseudoplatystoma corruscans (Agassiz) (Pisces: Pimelodidae). Ciência e Cult. 42: 997-1002.

1991. Redescription of Nomimoscolex piraeeba Woodland, 1934 (Cestoda: Proteocephalidea) from the Amazon catfishes, Brachyplatystoma spp. with proposal of synonyms and invalidation of Endorchiinae and Endorchis. Mem. Inst. Oswaldo Cruz 86 (2): 229-232.

1992. Redescription of Gibsoniela mandube (Woodland, 1935) (Cestoda: Proteocephalidea) a parasite of Ageneiosus brevifilis (Pisces: Siluriformes), and reapraisal of the classification of Proteocefalideans. Mem. Inst. Oswaldo Cruz 87 (3): 417-422.

1994. Order Proteocephalidea Mola, 1928, p.257-293. In: L.F. KHALIL; A. JONES \& R.A. BRAY (Eds). Keys to the Cestode parasite of Vertebrates. London, CAB International, 751p.

Rego, A.A. \& G.C. PAvanelli. 1985. Jauella glandicephalus gen.n. sp.n. e Megathylacus brooksi sp.n. cestóides patogênicos para o jau, Paulicea luetkeni, peixe pimelodideo do Brasil. Rev. Brasil. Biol. 45 (4): 643-652.

1987. Cestóides proteocefalídeos do jau, Paulicea luetkeni, peixe pimelodideo do Brasil. Rev. Brasil. Biol. 47 (3): 357-361.

1990. Novas espécies de cestóides proteocefalídeos parasitas de peixes náo siluriformes. Rev. Brasil. Biol. 50: 91-101.

1992. Check-list of the Cestode Order Proteocephalidea parasites from

South America freshwater fishes. Rev. Unimar 14 (Supl.): 109-137.

1992. Redescrição de Nomimoscolex admonticellia (Woodland, 1934) (Cestoda: Proteocephalidea), parasito de Pinirampus pirinampu (Spix) um siluriforme de água doce. Revta bras. Zool. 9 (3/4): 283-289.

SChAeFFER, G.V. \& A.A. Rego. 1992. Peritoneal and visceral cestode larvae in Brazilian freshwater fishes. Mem. Inst. Oswaldo Cruz 87 (Supl. I): 257-258.

SCHMIDT, G.D. 1986. Handbook of Tapeworm identification. Florida, CRC Press, 675p.

WARdLE, R.A. \& J.A. MC LEOD, 1952. The Zoology of Tapeworms. Minnesota, University of Minnesota Press, 780p.

WoOdLAND, W.N.F. 1924. On a new Bothriocephalus and a new genus of Proteocephalidae from Indian freshwater fishes. Parasitol. 16: 441-451.

. 1925. On three new Proteocephalids (Cestoda) and a revision of the genera of the family. Parasitol. 17 (4): 370-394.

-1933a. A new subfamily of Proteocephalid cestodes, the Othinoscolecinae, from the Amazon Siluroid fish, Platystomatichthys sturio (Kner). Parasitol. 25: 491-500.

1933b. On two new cestodes from the Amazon Siluroid fishes, Brachyplatystoma vaillanti Cuv. and Val. Parasitol. 25: 485-490.

1933c. On the anatomy of some fish cestodes described by Diesing from the Amazon. Quart. Jour. Micr. Sci. 76: 175-208. 
1934a. On the Amphilaphorchidinae, a new subfamily of Proteocephalid cestodes and Myzophorus admonticellia gen. n. sp. n. parasitic in Pinirampus spp. from the Amazon. Parasitol. 26: 141-149.

. 1934b. On some remarkable new cestodes from the Amazon Siluroid fish, Brachyplatystoma filamentosum (Licht.). Parasitol. 26: 267-277.

. 1934c. On six new cestodes from Amazon fishes. Proc. Zool. Soc. London: $33-41$.

1935a. Some more remarkable cestodes from the Amazon Siluroid fishes. Parasitol. 27: 207-225.

1935b. Some new Proteocephalids and a Ptychobothriid (Cestoda) from the Amazon. Proc. Zool. Soc. London: 619-623.

1935c. Additional cestodes from the Amazon Siluroids, Pirarará, Dórad and Sudobin. Proc. Zool.Soc. London: 851-862.

Yamaguti, S. 1959. Systema Helminthum. 2. The Cestodes of Vertebrates.

New York, Interscience Publ. Co., 860p.

Recebido em 20.III,1995; aceito em 26.III.1996. 